\title{
Wireless electric energy transmission system and its recording system using PZEM004T and NRF24L01 module
}

\author{
Markus Dwiyanto Tobi, Vina N Van Harling \\ Saint Paul Polytechnic Sorong, Indonesia
}

\begin{tabular}{l}
\hline \hline Article Info \\
\hline Article history: \\
Received Jun 14, 2020 \\
Revised Nov 26, 2020 \\
Accepted Dec 10, 2020 \\
\hline
\end{tabular}

\section{Keywords:}

Electromagnetic induction

NRF24L01

PZEM004T

Wireless power transmision

Wireless technology

\begin{abstract}
Electrical energy can not be separated from the name $\mathrm{kWh}$ Meter, a tool used to measure and record the amount of electrical energy usage has a shortage of $\mathrm{kWh}$ meters can not be monitored remotely how much energy is used, so it is rather inconvenient for PLN officials to check the use of electricity for postpaid customers. This research was conducted to design a prototype of a wireless electrical energy transmission system and design a wireless electrical energy recording system using the NRF24L01 wireless transmitter module and the PZEM004T kWh meter module. The design in this study uses the principle of electromagnetic induction to transfer electrical energy at close range, while to transmit data, the authors use the NRF24L01 module. Besides, the authors use the PZEM004T module to measure various magnitudes. Based on the results of observations and measurements of the design of the tool, the authors found that the transmission of electrical energy using electromagnetic induction is not effective for longer distances because the energy lost in the air is getting bigger. So this technology needs to be further investigated. Besides, the measurement of electrical quantities using the PZEM module has a small difference (under $2 \%$ ) with measurements using a multimeter, so it can be said that the measurement with the PZEM004T module is effective.
\end{abstract}

This is an open access article under the CC BY-SA license.

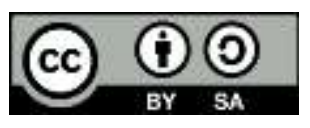

Corresponding Author:

Markus Dwiyanto Tobi

Saint Paul Polytechnic Sorong

Jl. R.A Kartini No. 1 Kampung Baru, Indonesia

Email: dwiyanto@poltekstpaul.ac.id

\section{INTRODUCTION}

The increasing number of human population causes problems to fulfill human needs more and more diverse [1]. One of them is meeting the needs in the field of energy resources to support the activities of daily human life. According to the Big Indonesian Dictionary (KBBI), energy is power (strength) that can be used to carry out various process activities, for example, it can be part of a material or not bound to the material (such as sunlight) [2]. Energy cannot be created nor can it be destroyed. Therefore to get a form of energy can be obtained by changing the energy in other forms [3, 4].

Electricity is an example of this form of energy. Electricity is the most flexible form of energy because it can be obtained from all forms of energy $[5,6]$. Because of its flexibility that is why electrical energy is the energy most widely used by humanity. Electricity cannot be separated from human life today, because almost every area/sector of life uses electricity as a source of energy [7], Besides, almost all office household equipment, hospitals, and others are electronic equipment that can be operated only with electricity [8]. 
The electrical energy that is often used in daily life is alternating electricity (AC) obtained from the results of generation through generators at power plant centers (power plants) [9, 10]. Electricity generated from the generator is then channeled through a conduit that ultimately leads to consumers [11]. In the process of channeling electrical energy through conductors, sometimes encountered various obstacles where the use of conductors is not reliable, such as thick walls that are high/wide, electrical loads that move around (mobile), humid and wet environments (such as bathrooms), etc. other. Besides, the heat that arises in the conductor as a result of the existence of internal resistance to the conductor can reduce the efficiency of energy transmission due to wasted energy $[12,13]$.

Talking about electrical energy is inseparable from the name kWh Meter, which is a device used to measure and record the amount of electricity used $[14,15]$. One of the shortcomings of $\mathrm{kWh}$ meters that is often found is that it cannot be monitored remotely how much energy is used, so it is rather inconvenient for PLN officers to check electricity usage for postpaid customers. Besides, the use of electrical energy that can be monitored directly from a distance can provide convenience for the homeowner [16-19].

Based on the description of the problems above, this research was carried out to design a prototype of a wireless electrical energy transmission system and design a wireless electrical energy recording system using the NRF24L01 wireless transmitter module and the PZEM004T kWh meter module.

\section{RESEARCH METHOD}

\subsection{Electric energy wireless transmission}

The basic working principle is to produce the largest frequency possible on the transmitter coil so that the energy efficiency distributed can be as large as possible. The working principle is shown in Figure 1.

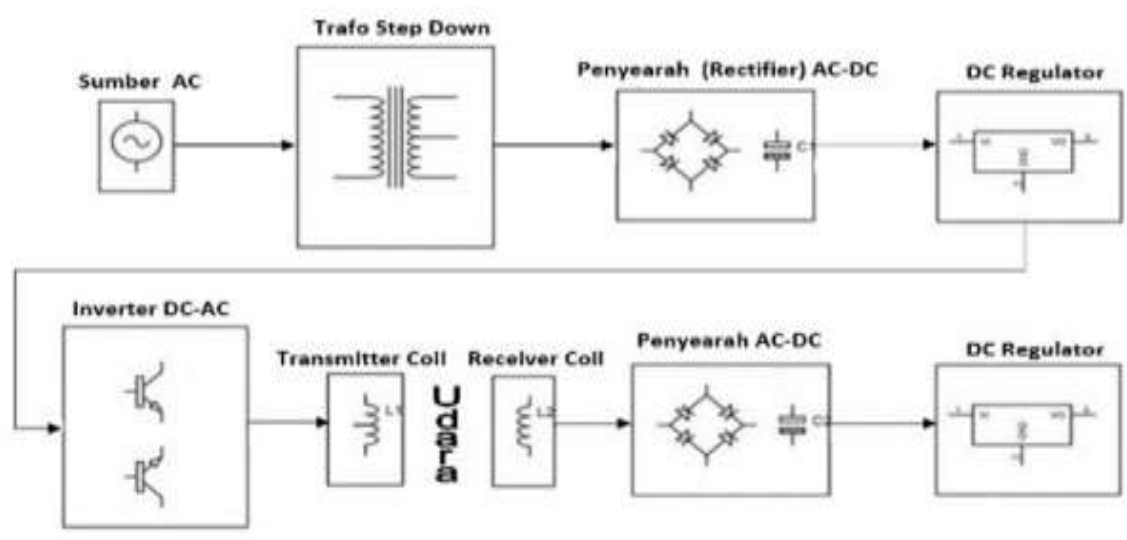

Figure 1. Work Block Diagram of Electric Energy Transmission System Through the Air

\subsection{Measurement and recording of electrical energy wirelessly}

The working system of this tool starts when the PZEM004T sensor detects voltage, current, power, and energy according to the installed load. The data is forwarded to Arduino for processing and the NRF24L01 module is forwarded as the data sender and the NRF24L01 module is accepted as the data receiver. This data is then forwarded to Arduino for further processing. The results of data processing are then sent to the LCD for display. The function of the buzzer is to give a warning when the use of electrical energy exceeds a predetermined limit. This work system can be seen in Figure 2 about the block diagram of the measurement and recording system of electrical energy wirelessly.

\subsection{Body design}

To make the tool body, the materials used are as follows: White plywood, plain plywood, Aluminum iron, Aluminum sheet, Aluminum elbow, $360^{\circ}$ wheel, Mica glass, Hinges. While for body design drawings, the author uses the SketchUp Pro 2015 software as seen in Figure 3. While for body design drawings, the author uses the SketchUp Pro 2015 software. The appearance of the SketchUp pro-2015 interface can be seen in Figure 4. 


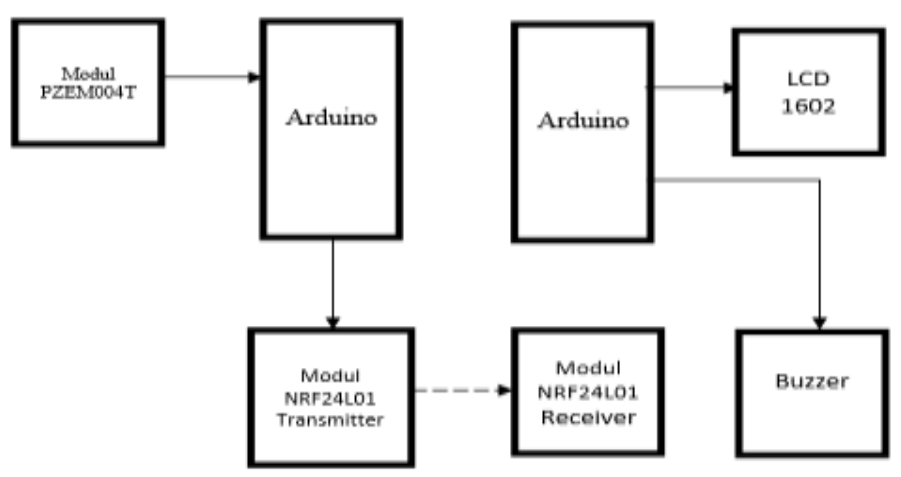

Figure 2. Block diagram of a system for measuring and recording electrical energy wirelessly

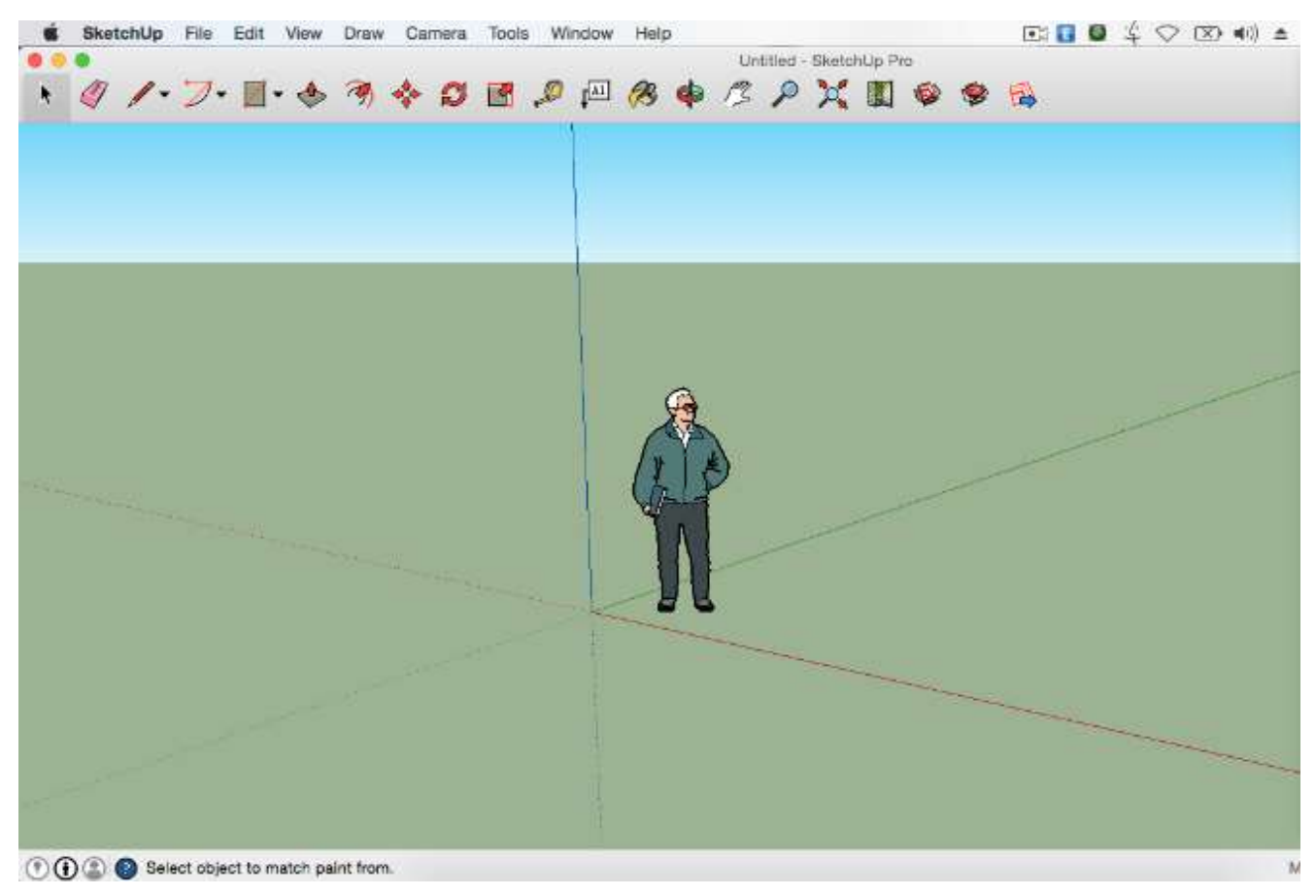

Figure 3. Display of SketchUp Pro 2015 User Interface

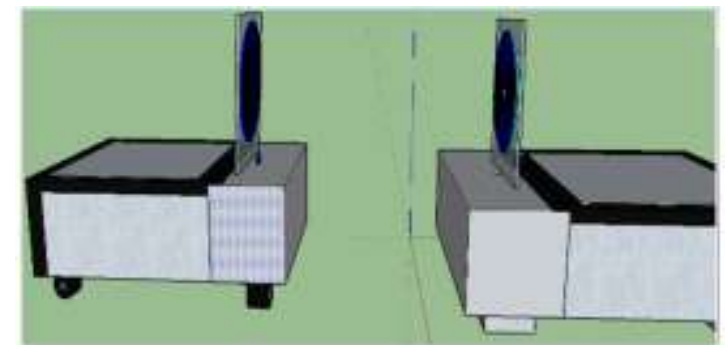

Figure 4. Tool body design

\subsection{Design of electronic circuits and modules}

1. Sender Series

The series of senders here for the 2 types, namely as shown in Figure 5, where the 2 types of images are:

a. Images with thin black lines and component images in the form of symbols are electronic circuits which are a series of electrical energy transmission systems. 
b. Images with thick colored lines and component images in their true form are a series of modules which are a series of electrical energy data transmission systems.

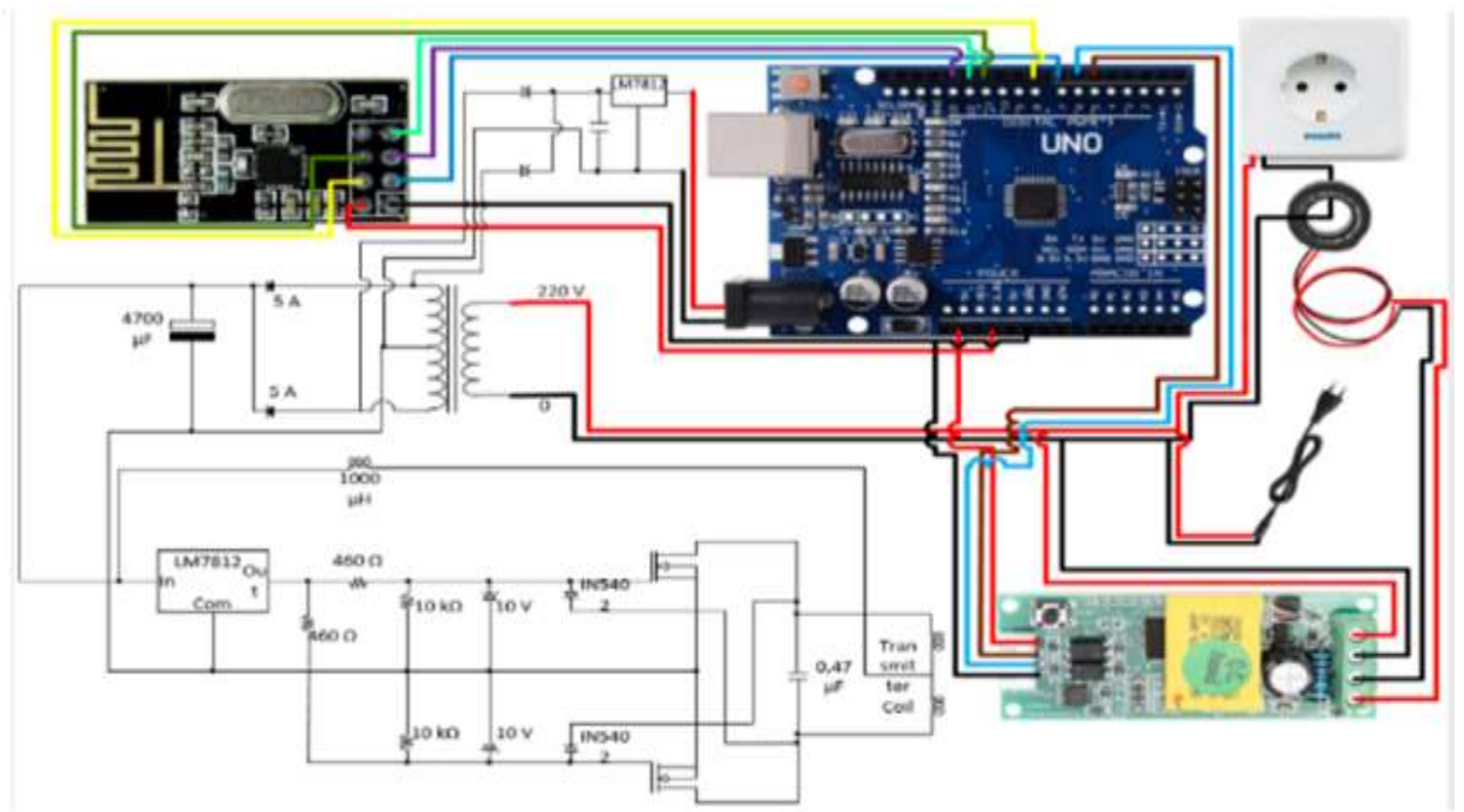

Figure 5. Sender circuit cable scheme

\section{Receiver Circuit}

The receiver circuit above consists of 2 receiver components, namely the NRF24L01 module as the data receiver and the receiver coil as the electrical energy receiver. Data received by NRF24L01 is forwarded to Arduino for further processing and display on the LCD and sound the buzzer if the electrical energy consumption exceeds the limit. The energy received by the receiver coil is used to turn on the LED as an indicator that electrical energy transmission is successful. a schematic drawing of the receiver circuit is presented in Figure 6.

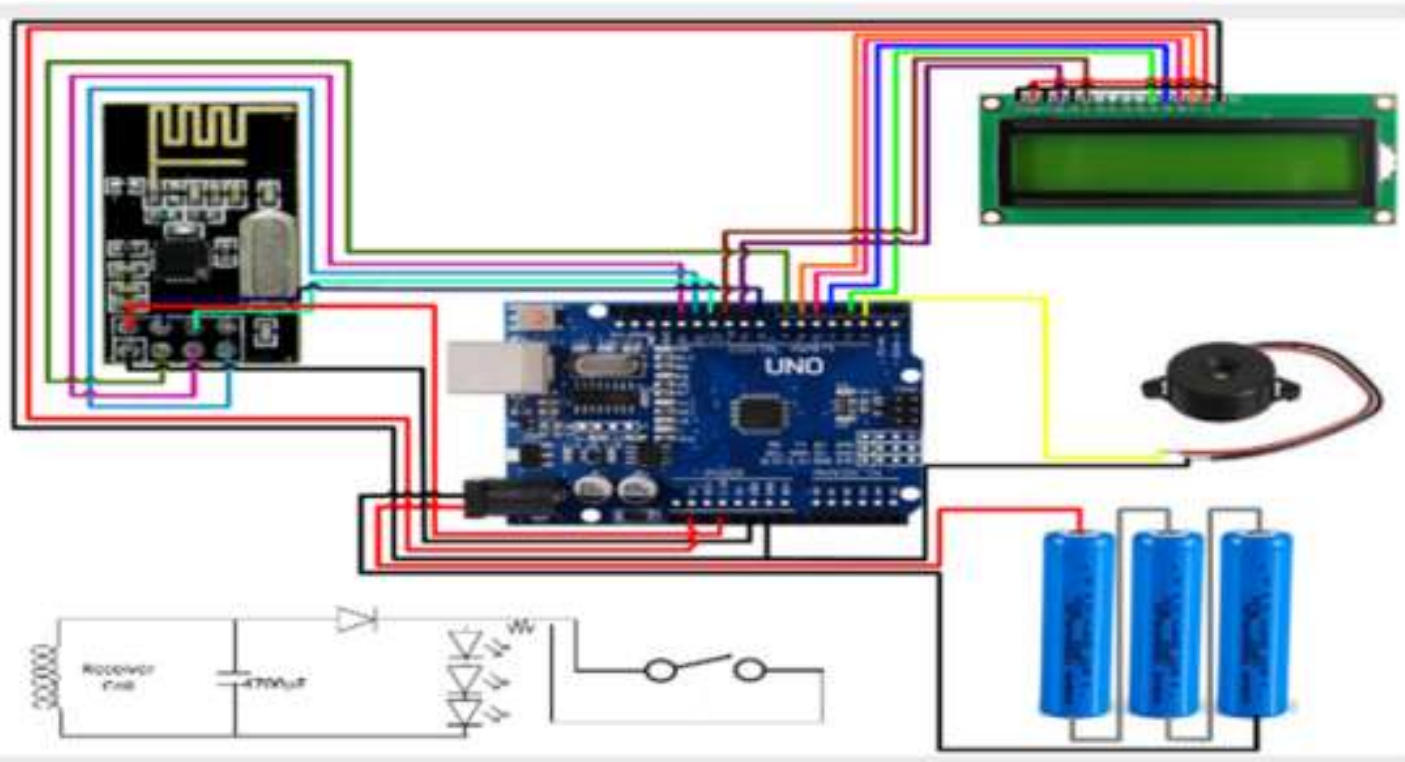

Figure 6. Receiver circuit wiring scheme 


\subsection{Programming language design}

For modules and components that have been assembled to work following the intended purpose, it is necessary to program the Arduino module [20-22]. Arduino as the brain regulates the direction of data flow from input to output and works according to the algorithm [23]. The programming language used in the Arduino module is $\mathrm{C}++$, while the compiler that I use is Arduino IDE $1.87[24,25]$.

\section{RESULTS AND DISCUSSION}

\subsection{General explanation}

The main circuit for sending electrical energy without wires is shown in Figure 7.

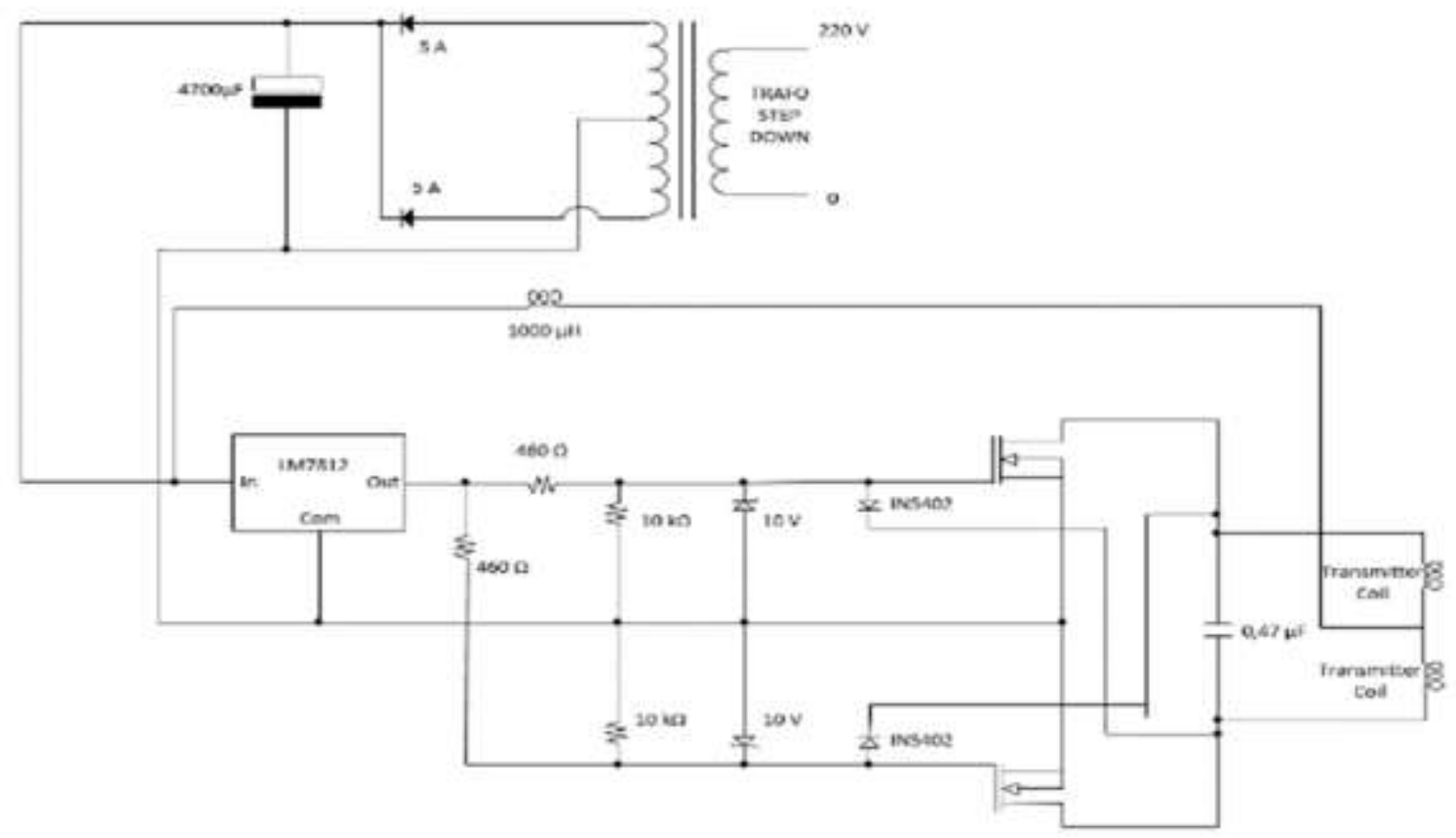

Figure 7. The main circuit of sending electrical energy wirelessly

\subsection{Work principle}

Electricity flows into the transformer and is reduced from 220volts of the primary side to 12 volts of the secondary side. Placement of 2 diodes 5A is as a full-wave rectifier [26]. Passing the capacitor as a filter toward the dc regulator. The output of this DC regulator is a straight DC (constant). From the voltage regulator exit to the gate mosfet. But before heading to the gate current will flow through the diode IN5402 towards the capacitor and the sending coil (capacitor filling). Because IN5402 diode resistance is very small (forward bias resistance) so that most of the current will flow through the diode, as a result, the gate is not triggered and the mosfet is OFF. When the capacitor has finished charging, the capacitor will act as a 'battery' so that most of the current will pass through the mosfet gate, so the mosfet is ON. Because the mosfet ON will be the current from the capacitor will not flow into the coil (because of the large coil resistance) but flows through the drain to the source mosfet. When the capacitor is used up, the current flows back to the diode and the mosfet is OFF and this process will repeat continuously. Thus, oscillations occur in the sending coil circuit.

The goal to be achieved from the above circuit is to produce oscillating electrical energy (AC) with a very high frequency in the sending coil (transmitter coil). Changes in the electric field (because electricity continues to oscillate with a large frequency) causes changes that are directly proportional to the magnetic field. Therefore, if we place a conductor (receiver coil) in a changing magnetic field, then according to the GGL induction law that "if a conductor is enclosed by a changing magnetic line of force, then between the ends of the conductor will appear different potential ". The magnitude of the induced emf is $\varepsilon=-N \frac{\Delta \phi}{\Delta t}$. From the equation, it is seen that to obtain a largely induced emf, large magnetic flux changes are needed in the smallest time possible. That is why the frequency of electricity used must be high. 


\subsection{Testing of wireless electric energy transmission systems}

\section{1) IC 7812}

Tests carried out by looking at the amount of voltage that comes out at the foot of the IC output when the input is given a certain voltage.

2) Diode $1 \mathrm{~N} 5402$

Tests carried out by looking at the value of resistance between the cathode foot and the anode during the forward bias and reverse bias states.

3) IRF2807

The test is done by measuring the amount of resistance between the drain and source feet when there is no potential difference between the gate and source feet and when there is a potential difference between the gate and source feet.

4) Measurement of maximum and minimum distance

Maximum distance: $13 \mathrm{~cm}$

Minimum distance: $3 \mathrm{~cm}$

At a distance of less than $3 \mathrm{~cm}$, there will be a back induction from the receiving coil on the sending coil. This is indicated by the occurrence of small vibrations in the sending circuit. At a distance of more than $13 \mathrm{~cm}$, the voltage induced on the receiving coil is too small, so that the LED does not light up.

5) Measurement of voltage to variable distances (no load)

Result of measurement of voltage to variable distances without load is presented in Table 1 . The measurement results shown in the table above are presented in graphical form in Figure 8.

Table 1. Results of measurements of output voltage over distance variables

\begin{tabular}{cc}
\hline Distance between coild $(\mathrm{cm})$ & Output voltage (volt) \\
\hline 3 & 12 \\
5 & 8,6 \\
7 & 7,7 \\
9 & 5 \\
11 & 2 \\
13 & 0,8 \\
\hline
\end{tabular}

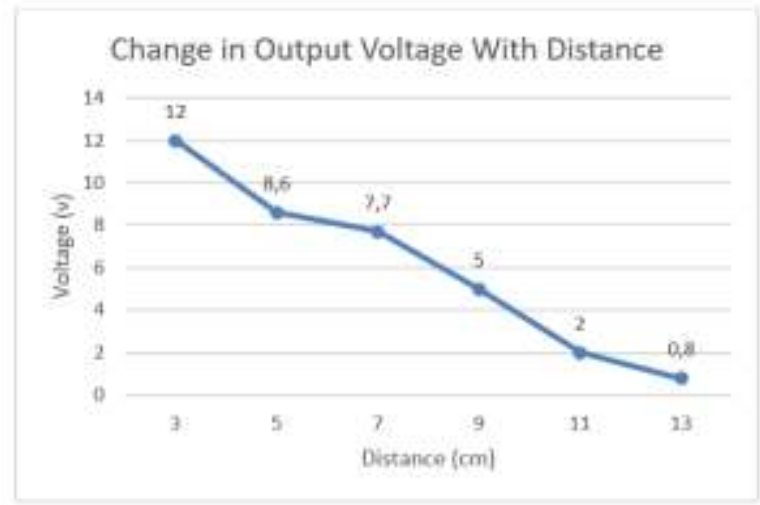

Figure 8. Change in output voltage with distance

6) Measurement of voltage to variable distance (with load)

Results of measurement of voltage to variable distance with load is presented in Table 2. The measurement results shown in the table above are presented in graphical form in Figure 9.

Table 2. Results of measurements of voltage to variable distances (with loads)

\begin{tabular}{cc}
\hline Distance between coil (cm) & Output voltage (Volt) \\
\hline 3 & 9,5 \\
5 & 7,6 \\
7 & 5,5 \\
9 & 3,7 \\
11 & 1,4 \\
13 & 0,8 \\
\hline
\end{tabular}

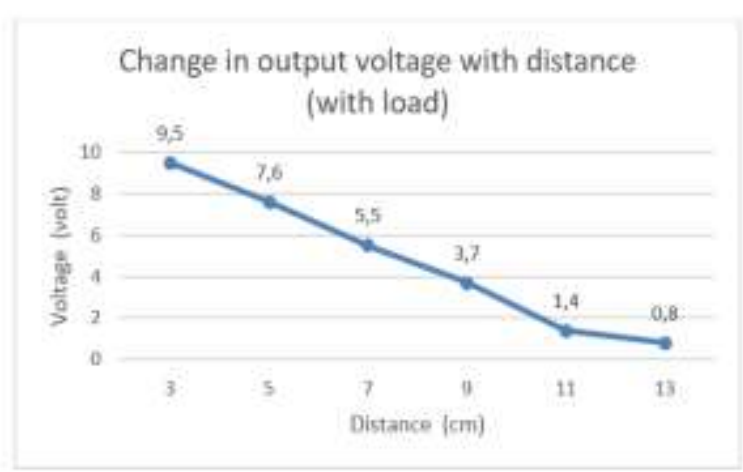

Figure 9. Change in output voltage with distance (with load) 
7) Remote Electrical Energy Recording System

The load that the author uses are: 12 Watt Philips Bulb, 40 Watt Solder, 108 Watt Fan, 240 Watt Drill, 570 Watt Gurinda.

8) PZEM004T module reading

The results of the PZEM004T module readings from the test results are presented in Table 3.

Tabel 3. Result of PZEM004T module reading

\begin{tabular}{cccc}
\hline Beban & Voltage (Volt) & Flow (Ampere) & Power (Watt) \\
\hline 12 Watt Philips bulb & 204 & 0,07 & 10 \\
40 Watt Solder & 203,6 & 0,13 & 27 \\
108 Watt fan & 200 & 0,44 & 87 \\
240 Watt drill & 199,10 & 0,5 & 100 \\
570 Watt Grinding & 198 & 0,92 & 183 \\
\hline
\end{tabular}

9) Voltage Measurement

The formula for calculating the difference in measurement error is as follows:

$\frac{\mid \text { Multimeter measuring voltage }- \text { PZEM004T measuring voltage } \mid}{\text { Multimeter measuring voltage }} \times 100 \%$

Based on the above equation, can be calculated the difference in error for measuring the voltage drop against the load being tested which is presented in Table 4. The voltage difference obtained from the measurement results with the PZME004T module on the multimeter measured voltage measurement results is shown in Figure 10.

Tabel 4. Result of Voltage Measurement

\begin{tabular}{cccc}
\hline Load & $\begin{array}{c}\text { The measured voltage of the PZEM004T } \\
\text { module (Volt) }\end{array}$ & $\begin{array}{c}\text { Measured voltage } \\
\text { Multimeter (Volt) }\end{array}$ & $\begin{array}{c}\text { Error Difference } \\
(\%)\end{array}$ \\
\hline 12 Watt Philips bulb & 204 & 205 & $0,48 \%$ \\
40 Watt Solder & 203,6 & 204 & $0,196 \%$ \\
108 Watt fan & 200 & 200 & $0 \%$ \\
240 Watt drill & 199,10 & 200 & $0,45 \%$ \\
570 Watt Grinding & 198 & 195 & $1,53 \%$ \\
\hline
\end{tabular}

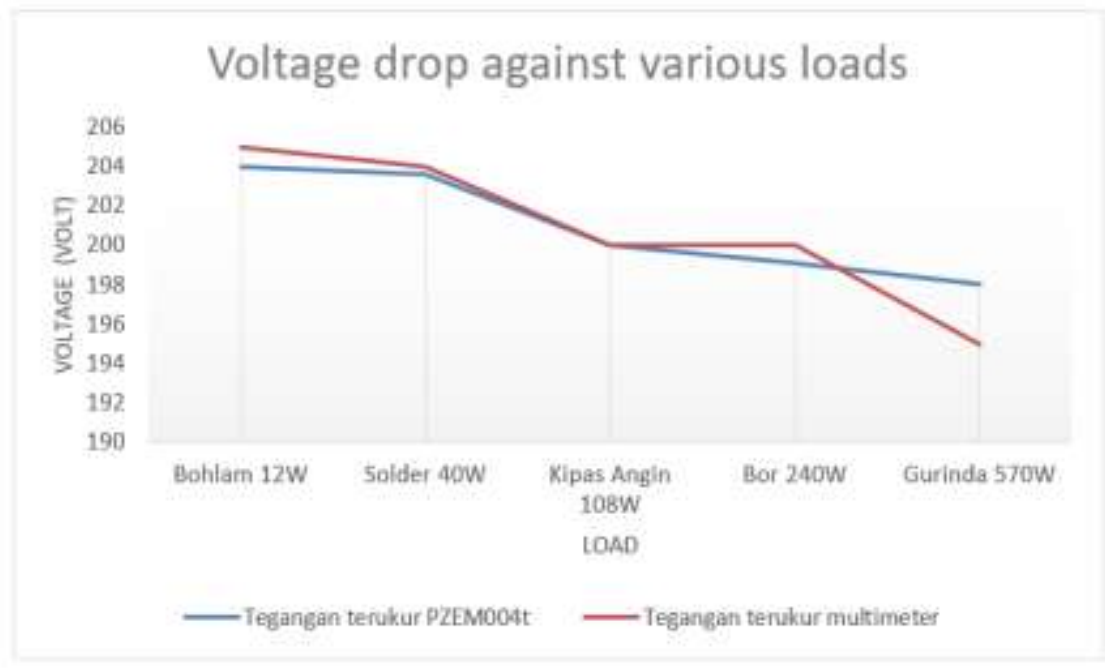

Figure 10. voltage drop against various loads 


\section{CONCLUSION}

The conclusion obtained from the wireless energy transmission system is: the amount of voltage induced in the receiving coil is inversely proportional to the distance between the two coils. The greater the distance between them, the smaller the induced voltage. The greater the distance between the two coils, the dimmer the light will be, which indicates that the power received by the lamp is getting smaller. The farther from the coil, the fewer lines of magnetic force so that it can be concluded that energy is lost in the air. Mounting loads can cause large stress drops. Meanwhile, for the Wireless Electrical Energy Recording system are: Measurement of electrical quantities using the PZEM004T module can be said to be accurate because it has a difference between the measurement error and the Multimeter below 5\%. The greater the electric load, the greater the voltage drop, and the greater the load, the greater the difference in measurement percentage.

\section{ACKNOWLEDGEMENTS}

Thank you to the Saint Paul Sorong Polytechnic for their support during the research.

\section{REFERENCES}

[1] Anwar, Yogie El dan Soedjarwanto, Noer, "Prototype Penggerak Pintu Pagar Ototmatis Berbasis Arduino Uno ATMEGA 328P dengan Sensor Sidik Jari,” Electrician, vol. 9. no. 1, pp. 33-37, 2015.

[2] Purnamasari, Indah, "Pengukuran Efek Temperatur Terhadap Resistansi Internal Dioda Semikonduktor," Universitas Islam Negeri Alauddin. Makassar, 2010.

[3] Sinclair, I dan Dunton, J., "Practical electronics handbook, sixth edition (6th ed)," Newnes, 2007.

[4] Umar, Efrizon, "Buku Pintar Fisika," Jakarta: Media Pusindo, 2008.

[5] Tobi, Markus Dwiyanto, and Vina N. Van Harling, "Pengendali Listrik Akses Parallel Port dengan Pemrograman Borland Delphi 7.0," Electro Luceat, vol. 4, no. 2, pp. 26-34, 2018.

[6] S A. Shaaya, et al, "Effect of optimal Multi-DG siting and sizing in transmission system using hybrid optimization technique for voltage control," Indonesian Journal of Electrical Engineering and Computer Science (IJEECS), vol. 17, no. 2, pp. 646-653, February 2020.

[7] Tobi, Markus Dwiyanto, "Pengaruh Optimasi Transformator Daya terhadap Perkembangan Beban Feeder untuk Meminimalisasi Gangguan dan Defisit Beban Listrik di Wilayah Sorong-provinsi Papua Barat," Electro Luceat, vol. 3, no. 1, pp. 10-18, 2017.

[8] Sogen, Markus Dwiyanto Tobi, "Analisis Pengaruh Ketidakseimbangan Beban terhadap Arus Netral dan Losses pada Transformator Distribusi di PT Pln (Persero) Area Sorong," Jurnal Electro Luceat, vol. 4, no. 1, 2018.

[9] Tobi, M. D., \& van Harling, V. N., "Study of PLTMH development planning in Sasnek village Sawiat district, South Sorong regency West Papua province," Indonesian Journal of Electrical Engineering and Computer Science (IJEECS), vol. 18, no. 2, pp. 678-687, 2020. https://doi.org/10.11591/ijeecs.v18.i2.pp678-687

[10] Abdulrahaman Okino Otuoze, Mohd Wazir Mustafa, Ibim Ebianga Sofimieari, Abdulhakeem Mohd Dobi, Aliyu Hamza Sule, Abiodun Emmanuel Abioye, Muhammad Salman Saeed, "Electricity theft detection framework based on universal prediction algorithm." Indonesian Journal of Electrical Engineering and Computer Science (IJEECS). vol. 15, no. 2, pp. 758-768, August 2019.

[11] K. B.Kela, Bhavik N.Suthar, L. D. Arya. "Reliability optimization of electrical distribution systems considering expenditures on maintenance and customer interruptions." Indonesian Journal of Electrical Engineering and Computer Science (IJEECS), vol. 14, no. 3, pp. 1057-1064, June 2019.

[12] Saiful Firdaus Abd Shukor, Ismail Musirin, Zulkifli Abd Hamid, Mohamad Khairuzzaman Mohamad Zamani, Mohamed Zellagui, Hadi Suyono. "Intelligent based technique for under voltage load shedding in power transmission systems." Indonesian Journal of Electrical Engineering and Computer Science (IJEECS). vol. 17, no. 1, pp. 110-117, January 2020.

[13] A. M. Agwa, H. M. Hassan, Z. E. Matter, E. A. Eisawy. "Electrical grid reliability assessment by fault tree analysis." Indonesian Journal of Electrical Engineering and Computer Science (IJEECS). vol. 17, no. 3, pp. 11271134, March 2020.

[14] Budiharto, Widodo dan Rahardi, Saftian, "Teknik Reparasi PC dan Monitor," Elex Media Komputindo, Jakarta, 2005.

[15] Diharjo, Sigit Julianto, "Rancang Bangun Transfer Daya Listrik Nirkabel Beban DC Menggunakan Induksi Elektromagnetik," Universitas Islam Indonesia, Yogyakarta, 2018.

[16] Sameer Abdul-Sattar Lafta, Aktham Hasan Ali, Marwah M. Kareem, Yasser A. Hussein, Adnan H. Ali. "Performance simulation of broadband multimedia wireless networks simulation based on OPNET." Indonesian Journal of Electrical Engineering and Computer Science (IJEECS). vol. 17, no. 1, pp. 1-9, January 2020.

[17] Ali Basim Mohammed, Mohd Aifaa Mohd Ariff, Sofia Najwa Ramli. "Power quality improvement using dynamic voltage restorer in electrical distribution system: an overview." Indonesian Journal of Electrical Engineering and Computer Science (IJEECS). vol. 17, no. 1, pp. 86-93, January 2020.

[18] Chandrasekharan Nataraj, Mahsoom Raseen Abdul Careem, Ravi Lakshmanan, Sathish Kumar Selvaperumal, Raed Abdulla. Wireless charging system using spectral energy harvesting technique." Indonesian Journal of Electrical Engineering and Computer Science (IJEECS). vol. 15, no. 1, pp. 314-323, July 2019. 
[19] Md Rabiul Awal, Muzammil Jusoh, R. Badlishah Ahmad, Thennarasan Sabapathy, M. Najib M. Yasin, Mohd Hafizuddin Mat. "Designing cantilever dimension for low power wireless applications." Indonesian Journal of Electrical Engineering and Computer Science (IJEECS). vol. 14, no. 2, pp. 758-764, May 2019.

[20] Mismail, Budiono, "Dasar Teknik Elektronika,” Malang: Universitas Brawijaya Press, 2011.

[21] Murtadha, Raihan A., "Prototype Kulkas Portable dengan Memanfaatkan Efek Termoelektrik," Gorontalo: Madrasah Aliya Negeri Insan Cendekia, 2019.

[22] Pradana, Sunu, "Adaptasi Peralatan Penguji Kondisi ESR pada Kapasitor," Yogyakarta: Universitas Negeri Yogyakarta, 2013.

[23] Tobi, Markus Dwiyanto. "Rancang Bangun Robot Beroda Pemadam Api Menggunakan Arduino Uno Rev. 1.3," Electro Luceat, vol. 1, no. 1, 2015.

[24] Wilman, R dan Riyan, "Mengenali dan Mengatasi Kerusakan Software Handphone,” Depok: Kawan Pustaka, 2006.

[25] Iskandar, Akbar, et al. "Mobile based android application pharmaceutical dictionary with direct search as searching process," International Journal of Scientific and Technology Research, vol. 8, no. 6, pp. 44-46, 2019.

[26] Fauzi dan Syukriyadin, "Analisis Besaran Frekuensi Terhadap Daya Listrik Pada Rangkaian Transmisi Listrik Nirkabel,” KITEKTRO, vol. 3. no. 4. pp. 7-9, 2018.

\section{BIOGRAPHIES OF AUTHORS}

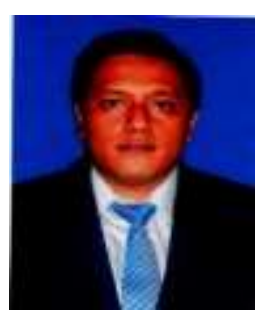

Markus Dwiyanto Tobi was born in Sorong, Indonesia in 1983. He earned his first degree in electrical engineering in 2007 at Jember University. In 2014 he obtained his Masters in Electrical Engineering from the Gunadharma University in Jakarta. He has been a lecturer since the Electrical Engineering Study Program (2009-present). His research interest include embedded systems, microcontroller systems, sensors and actuators, electric power system stability, and robotics engineering.

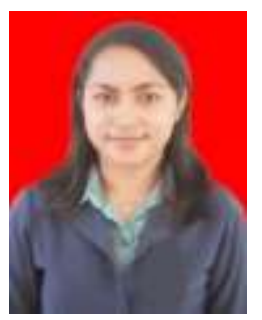

Vina N. Van Harling was born in Ambon, Indonesia in 1987. She earned her first degree in chemistry at Satya Wacana Christian University Salatiga in 2008 and completed her Masters in Educational Management Study Program at the Satya Wacana Christian University Salatiga in 2011. Currently, the author is actively teaching at the Saint Paul Polytechnic Sorong in the Mechanical Engineering and Electrical Engineering study program. Her research interest include applied chemistry, research methods, statistics, and experimental design. 